\title{
Applying Programmable Logic Control (PLC) for Control Motors, Blower and Heater in the Rubber Drying Processing
}

\author{
Hendra ${ }^{1}$, Pebriyanto S. ${ }^{2}$, Hernadewita ${ }^{3}$, Hermiyetti ${ }^{4}$, Yoserizal ${ }^{5}$ \\ ${ }^{1}$ Mechanical engineering dept. University of Sultan Ageng Tirtayasa Banten, J1.Jenderal Sudirman KM 3, Cilegon 42435, Indonesia \\ ${ }^{2}$ Mechanical engineering dept. University of Bengkulu, J1.W.R. Supratman, Bengkulu, 38371, Indonesia \\ ${ }^{3}$ Magister industrial engineering University of Mercubuana Jakarta, Jl.Meruya Selatan, Jakarta 11650, Indonesia \\ ${ }^{4}$ Faculty of Economic University of Bakrie, Jl. HR Rasuna Said Kuningan, Jakarta, 12920, Indonesia \\ ${ }^{5}$ Mechanical engineering dept. Andalas University, Kampus Limau Manis, Padang, 25163, Indonesia
}

\begin{tabular}{l} 
ARTICLE INFO \\
\hline Article history: \\
Received April 04, 2021 \\
Revised April 18, 2021 \\
Accepted April 28, 2021
\end{tabular}

\section{Keywords:}

Programmable Logic Controller; PLC;

Control;

Rubber Dryer;

Heater Machine;

Temperature Sensor

\begin{abstract}
Rubber is the largest commodity in Indonesia. Rubber is traditionally processed and dried using bamboo hangers, manual arrangement of bamboo drying rubber, heat from firewood for drying chambers and large areas. This drying process has disadvantages, namely inconsistent drying time, nonuniform room temperature, unequal product quality, and unfriendly drying process. The solution is to overcome the automatic rubber dryer machine that is made using PLC to get the motor operating system for automatic rubber handling in the drying chamber, fixed drying temperature, small drying area, and fast-drying time. The experimental method is used for the automatic rubber drying process with PLC to control the movement of rubber in/out of the chamber dryer, heater, and blower for distribution temperature and other components. From the test results, it is found that the control system can work well at the voltage of each component of $220 \mathrm{~V}$, such as a sensor with a current of $0.21 \mathrm{~A}$ and a stop time of $0.01 \mathrm{~s}-0.3$ seconds. The motor, heater, and blower are active $(\mathrm{ON})$ at $220 \mathrm{~V}$ with a current of $8.27 \mathrm{~A}$. The heater requires a current of 1.99A for active $(\mathrm{ON})$ and an active blower $(\mathrm{ON})$ with a current of $0.75 \mathrm{~A}$.
\end{abstract}

This work is licensed under a Creative Commons Attribution-Share Alike 4.0

\section{Hendra}

Mechanical Engineering Dept. University of Sultan Ageng Tirtayasa Banten Indonesia, J1 Jenderal Sudirman KM. 3, Cilegon 42435, Indonesia

Email: hendra@untirta.ac.id

\section{INTRODUCTION}

Rubber is a major commodity product in Indonesia. Rubber plantations spread in several regions in Indonesia require a rubber processing process to meet the criteria or standards of dry rubber. The process of rubber processing is done traditionally by scraping the raw rubber from the tree, collected in a reservoir, and processed into a creep or SIR form. The dry quality of rubber (SIR) is very important as part of the acceptance of processed rubber products. Like quality rubber, SIR 1 has the criteria such as not having air bubbles on the inside of the dry rubber, and its color is clear. Several requirements must be considered to obtain rubber with SIR 1 quality, namely the drying room temperature in the range of $30^{\circ} \mathrm{C}-60^{\circ} \mathrm{C}$, the availability of an adequate heat source in the drying chamber, and the process of adjusting the position of the wet rubber in the drying room.

The process of manually drying wet rubber into dry rubber with SIR quality requires several stages, namely collecting the wet rubber, installing it on bamboo hangers, inserting the wet rubber trolley into the drying room, heating the drying room to $30^{\circ} \mathrm{C}$ (for three days) and fourth day to seven days with a temperature of $60^{\circ} \mathrm{C}$ and followed by process of smoking or spraying liquid smoke [1]. The resource of thermal energy is obtained from firewood flowing into the drying chamber. The process of controlling the heat and checking the temperature in the drying chamber is done manually by installing a thermometer on the wall of the drying chamber. This makes it difficult to obtain uniform temperature measurements in the dryer chamber. It is done 
after seven days of the drying processing in the drying room to check the condition and quality of the rubber. From the results of the inspection of the dry content of the rubber, if there are no air bubbles on the rubber, then this meets the quality of SIR 1 . But if there are some air bubbles that appear, insert the rubber, the quality of the rubber become decreases to the quality of SIR 2 and so on. This is very detrimental to the rubber company as some rubber that does not meet the desired requirements will be rejected by the ordering company.

Manual rubber drying processing has several disadvantages, namely inconsistent drying time, nonuniform room temperature, irregular rubber arrangement, requires a lot of bamboo for rubber hangers, unequal product quality, large drying area, and unfriendly drying process for the environment. The solution is to overcome the automatic rubber drying machine using PLC that is applied to control the system motor of automatic rubber dyer setting in the multi-storage room, fixed drying temperature, small drying area, and fastdrying time. The PLC will control the rubber drying process by regulating the movement of rubber in and out using a motion sensor, arrangement of rubber in the drying chamber, regulating the heating temperature in the drying chamber by activating the heater or blower, and so on. PLC has been used in many control systems such as rotary dryers for waste liquid processing, food processing, automotive part processing and etc. [2-17]. PLC application for the process control system or machine can be seen in pure milk processing using Omron CPM1A PLC, paint production process with TWIDO TWDLMDA20DTK PLC, Omron CP1L PLC as a control in moving goods into boxes, and others [7-10]. In addition to PLC, the control system can also be done using Arduino Uno, AT Mega, and others [18]. The control system in the rubber dryer machine uses PLC because it has advantages such as easy installation and maintenance, does not require a complicated wiring system, and so on [2].

The experimental method was used for an automatic rubber drying process with PLC to control the movement of rubber entering/leaving the chamber dryer, temperature, and other components such as heater and blower.

In this study focus on the control of component rubber dryer such as motor, blower, heater for rubber drying processing using Zelio Smart PLC, regulate the movement of rubber in and out, activation of heater and blower to regulate the temperature in the drying chamber, and arrange the arrangement of rubber in the drying chamber. The parameters to be adjusted are the room temperature between $30^{\circ} \mathrm{C}$ to $60^{\circ} \mathrm{C}$, the voltage of activation of the heating or cooling media if the temperature is reduced or excessive, set the time to enter the drying chamber.

\section{RESEARCH METHOD}

An experimental method has been used in this research by making a control system component rubber dryer machine using Zelio smart PLC. PLC application for the process control system or machine can be seen in pure milk processing using Omron CPM1A PLC, paint production process with TWIDO TWDLMDA20DTK PLC, Omron CP1L PLC as a control in moving goods into boxes, PLC for energy research, industrial control applications, and monitoring of plants, water, and wastewater management control, PLC for the control system in manufacturing automation, PLC for product sorting and packaging based on color detection and others [4-11].

The automatic rubber drying machine control system using PLC consists of designing software by creating a ladder program. The flow of this research process can be seen in Fig. 1. The drying process is started by observing the rubber drying process manually in a rubber processing and drying company, followed by a literature review for the design and design of automatic rubber dryers, design, and manufacture of ladder programs for the work of dryer machine components such as sensors, motors, and gearboxes, heaters, and blowers. Continue with the ladder program input into the PLC connected to the rubber dryer component network. Start by pressing the start button to start the rubber dryer. When rubber is detected by the rubber reception sensor (sensor 1), sensor one will tell the PLC to order the motor and gearbox to be active.

The working time of sensor 1 to work is adjusted according to the measurements of -1 to the 9 th rubber dimension used plus a second detector sensor of the rubber long end detector -1 to nth. Next, the motor and gearbox will move the rubber towards the entrance to the drying chamber, where there is sensor 3 . Then the rubber is arranged to fill the drying chamber, and after sensor three detects all the rubber fills the drying chamber, the heater or blower will be active to distribute heat to the chamber drying. The heater will be active if the temperature is below $30^{\circ} \mathrm{C}$. The heater will turn off when the temperature is above $600^{\circ} \mathrm{C}$. When the heater is off, the blower circulation will actively disperse the hot air in the drying chamber until the dryer room temperature is evenly distributed at $300^{\circ} \mathrm{C}-600^{\circ} \mathrm{C}$. If the temperature is above $600^{\circ} \mathrm{C}$, the evacuation blower will blow air out of the drying room until the drying room temperature is maintained at $300^{\circ} \mathrm{C}-600^{\circ} \mathrm{C}$. The process lasted for seven days according to the drying time of the company, and the quality of the rubber was measured visually and the moisture content.

Applying Programmable Logic Control (PLC) for Control Motors, Blower and Heater in the Rubber Drying Processing (Hendra) 


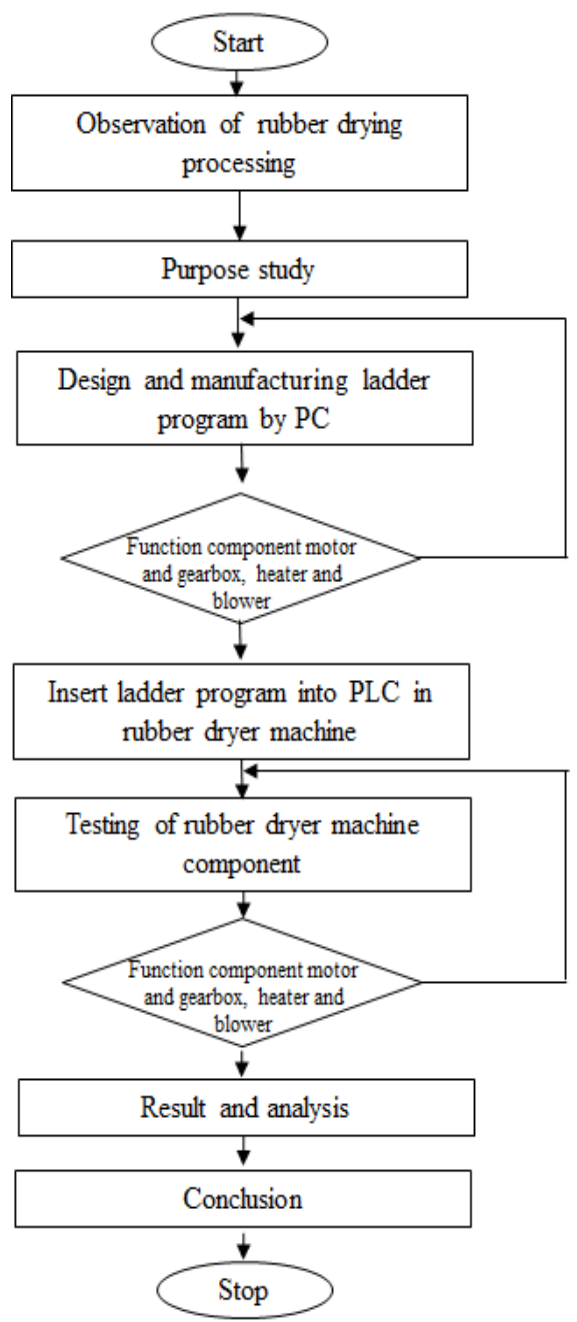

Fig. 1. Flowchart of research activity

In this study, PLC SR3B261FU Zelio smart relay types are used for the control system in the rubber dryer machine, as shown in Fig. 2(a). with input voltage specifications of $24 \mathrm{~V}$, current $4 \mathrm{~mA}$, and input number 16, 10 relay output and output voltage limits of $5-30 \mathrm{~V}_{\mathrm{DC}}$ and $24-250 \mathrm{~V}_{\mathrm{AC}}$ as shown in Table 1 . The PLC programming using the ladder program is shown in Fig. 2(b).

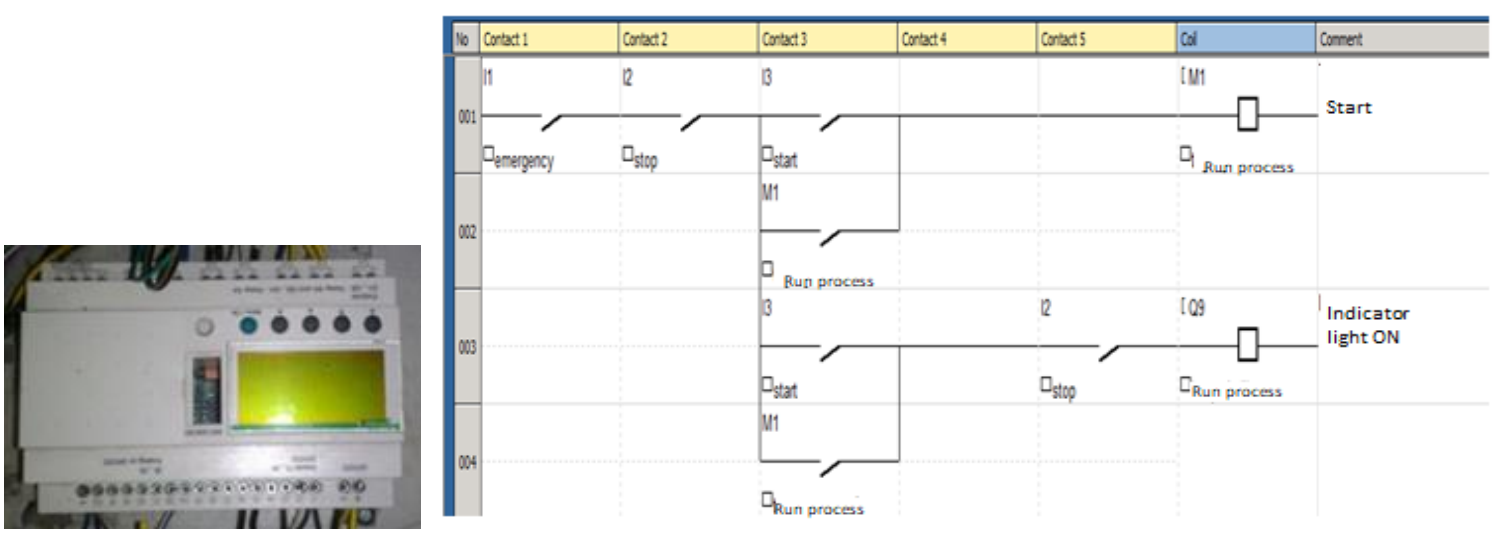

(a) PLC

(b) Ladder program PLC

Fig. 2. PLC Zelio Smart Relay SR3B261FU 
Rubber drying machine components consist of drying chamber, sensor insert and out motion rubber and temperature sensor, chain drive motor, rubber hook chain, heater, blower, thermometer, gear, PLC, and others. The components of this rubber dryer can be seen in Fig. 3. The details of the components of this rubber dryer are:

\section{Drying chamber}

The dryer chamber has specifications of $4000 \mathrm{~mm}$ length, $2000 \mathrm{~m}$ width, and $2000 \mathrm{~m}$ height. The dryer chamber is made of a stainless steel frame with a size of $40 x 60 \mathrm{~mm}$. The walls of the dryer chamber are made of glass or plastic.

2. PLC

The PLC used by the Schneider is a type of smart Zelio relay with the shape and specifications that can be seen in Table 1.

3. Motor and gearbox

The motor and gearbox used has specifications: power $0.12-4 \mathrm{KW}$ and rotation of $1400 \mathrm{rpm}$, as can be seen in Fig. 4 and Table 2.

4. Shaft and sprocket

The shaft is the handle of the sprocket that will move the rubber hook chain. The shaft and chain are made of steel.

5. Proximity and temperature sensors

A proximity sensor is used to read the wet rubber so that the PLC will activate the motor and the gearbox moves to bring the rubber to the dryer chamber.

6. Blower and heater

Blowers are used to circulating air in the drying chamber and remove air from the drying chamber if the temperature of the drying chamber is more than $60^{\circ} \mathrm{C}$. The heater serves to transfer heat to the drying chamber if the air temperature is less than $30^{\circ} \mathrm{C}$.

7. Chains and hangers for rubber

Chains and hangers serve to attach the wet rubber and carry it into the dryer chamber.

Table 1. Specification of PLC Zelio Smart Relay SR3B261FU

\begin{tabular}{clc}
\hline No & \multicolumn{1}{c}{ Item } & Value \\
\hline 1 & Product or component type & Modular Smart Relay \\
2 & Local display & With \\
3 & Clock & With \\
5 & Use rate supply voltage & $24 \mathrm{~V}$ \\
7 & Discrete input number & 16 \\
8 & Discrete input voltage & $24 \mathrm{VDC}$ \\
9 & Discrete input current & $4 \mathrm{~mA}$ \\
10 & Analog input number & 6 \\
11 & Analog input range & $0-24 / 0-10 \mathrm{~V}$ \\
12 & Number of outputs & 10 Relay output \\
13 & Output voltage limits & $5-30$ VDC (Relay output) \\
& & 24- 250VAC (Relay output) \\
\hline
\end{tabular}

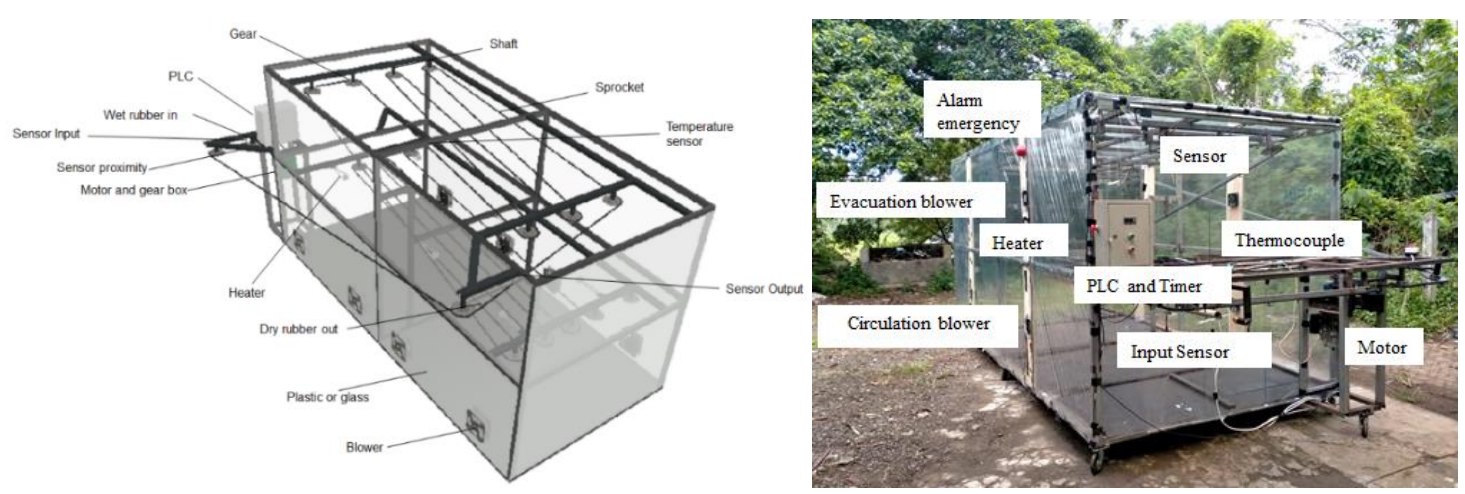

Fig. 3 Rubber dryer machine and components 


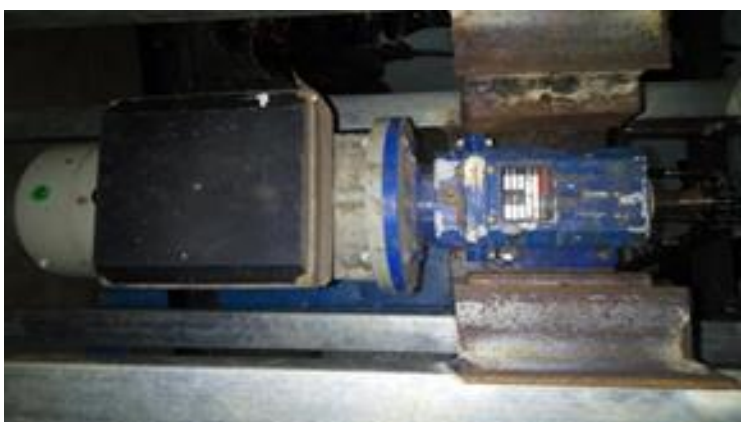

Fig. 4 Motor and gearbox

Table 2. Specification of motor Yuema helical gear box

\begin{tabular}{cc}
\hline Type & CHCFP (IEC) \\
\hline Sizes & $01-01-03-04$ \\
Rpm max (1400rpm) & $500 \mathrm{Nm}$ \\
Ratio & $3.66-54$ \\
Power & $0.12-4 \mathrm{~kW}$ \\
\hline
\end{tabular}

The temperature measuring points using digital thermometers in the rubber dryer chamber are located at the front, top, bottom, left, and right of the drying chamber. The installation arrangement of the rubber dryer temperature gauge can be seen in Fig. 5.

The working principle of this rubber dryer is that the wet rubber material detected by the input sensor will provide information to the PLC to activate the actuator motor to bring the wet rubber to the dryer chamber. Once the wet rubber is arranged and full in the rubber drying chamber, then the rubber drying system starts operating. The initial heat of the drying system is obtained from the sun's heat trapped in the drying chamber, thus increasing the temperature in the drying chamber. The temperature in the drying chamber is set between $30^{\circ} \mathrm{C}$ into $60^{\circ} \mathrm{C}\left(50^{\circ} \mathrm{C}\right)$ [19]. If the temperature in the drying chamber is below $30^{\circ} \mathrm{C}$ then the heater will be active to transfer heat to the drying chamber using an air jet blower. If the temperature is above $60^{\circ} \mathrm{C}$, the blower will be active to circulate air out of the drying chamber. At night the heating system of the drying chamber uses a heater with an air temperature setting between $30^{\circ} \mathrm{C}$ into $60^{\circ} \mathrm{C}$. The process of drying wet rubber is done for seven days by measuring the moisture content produced by the dry rubber. Once the moisture content of the rubber is dry, the PLC will command the active motor and remove the rubber from the drying chamber. After that, the dimensions, weight, and quality of the rubber are measured visually by a lighting process so that air bubbles in the dry rubber can be seen. If a lot of air bubbles are trapped in the dry rubber, the quality of the rubber is low, and on the other hand, if there are no air bubbles, the quality of the rubber is good (SIR 1). Fig. 6 shows the quality of dry rubber visually inspected using illumination.

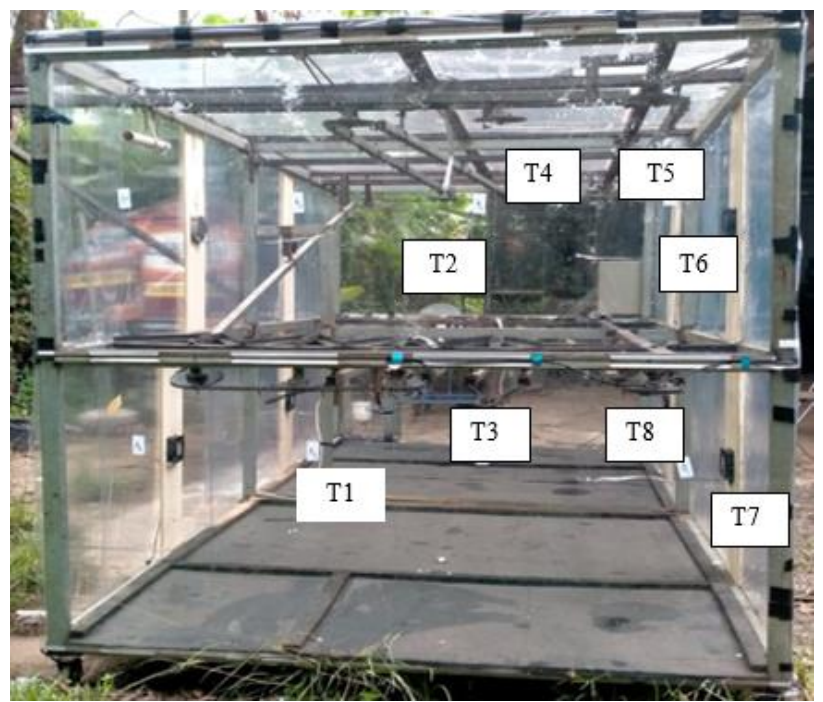

Fig. 5 Position sensor of temperature using thermocouple

Applying Programmable Logic Control (PLC) for Control Motors, Blower and Heater in the Rubber Drying Processing (Hendra) 


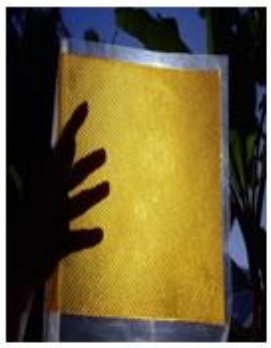

Good

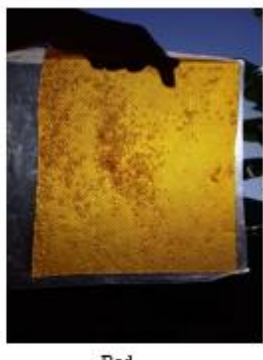

Bad

Fig. 6 Quality of SIR rubber

\subsection{Ladder Program of PLC}

The automatic rubber dryer control system with PLC using ladder program. The stages of creating a ladder program are:

1. Make a blog diagram of the automatic rubber dryer control system.

The blog diagram of the automatic rubber drying machine control system can be seen in Fig. 7. As shown in Fig. 7, wet rubber is hung on a hook hanger chain and detected by an input sensor to enter the drying chamber through the activation of the motor and gearbox. The motor moves a chain containing rubber to the drying chamber until it is arranged to fill the drying chamber. Once the wet rubber is fully stacked in the drying chamber, the rubber drying process will run with the temperature setting between $30^{\circ} \mathrm{C}$ into $60^{\circ} \mathrm{C}$ and drying time for seven days. Once the rubber is dry, the proximity sensor will signal to the PLC to remove the rubber from the drying chamber.

2. Create a ladder program using a PC and insert the program into the PLC consisting of ordering rubber, voltage $\mathrm{ON} / \mathrm{OFF}$, indicator light $\mathrm{ON} / \mathrm{OFF}$, activation motor and gearbox ON/OFF, timer ON/OFF, heater and blower ON/OFF, and setting time for drying process at seven days.

3. Then the control program on the PLC is activated on the rubber dryer to move the machine components, and component performance tests are carried out, which include: the working test of sensor 1 (when rubber is first detected), sensor 2 (when rubber is detected moving into the dryer room), sensor 3 (when the first rubber is in the drying chamber) in the form of working voltage and pause, motor motion test and gearbox, heater, circulation blower and evacuation in the form of voltage-current $\mathrm{ON}$ and OFF.

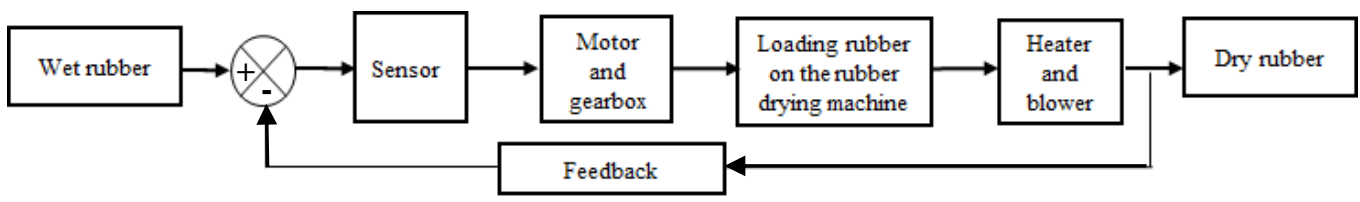

Fig. 7. Block diagram of the control system of rubber dryer machine

\section{RESULTS AND DISCUSSION}

In testing the automatic rubber dryer machine, using PLC greatly helps the rubber drying process to produce rubber with SIR 1 quality. SIR 1 rubber quality has product criteria with rubber drying result without air bubbles on the inside of the rubber. If the dry rubber has air bubbles in it, the quality of this rubber will be low and can be processed back into creeping rubber. The result of automatic rubber drying using PLC has obtained results in accordance with the quality of SIR 1 rubber where it starts by making ladder program on PC, followed by transferring ladder program into PLC and operating an automatic rubber dryer machine using PLC.

The results of manufacturing and testing of ladder program for automatic rubber drying machine control system using PLC can be seen in Fig. 8. Fig. 9 shows the PLC ladder program for the working condition of rubber dryer machine components where in the figure shows a ladder program inserted into a PLC system, as shown in Fig. 8, which can serve to regulate the movement of wet rubber into the drying chamber until the dry rubber exits in the dryer chamber (see Fig. 9). They are starting from the input voltage when the wet rubber is hung on a hook hanger on the chain, followed by the PLC commands. The motor and gearbox move to bring the wet rubber to the drying chamber and fill the drying chamber according to the dried rubber capacity. Once the rubber fills the drying chamber, the drying process is started, and the drying time is adjusted to seven days. During the seven days, the heater actively conducts heat to the drying chamber by using a circulation blower in case of the heat from solar energy is cannot enough to supply heat from a temperature of $30^{\circ} \mathrm{C}$ to $60^{\circ} \mathrm{C}$. When 
the drying room temperature exceeds $60^{\circ} \mathrm{C}$, the evacuation blower will work to remove hot air in the drying chamber. After seven days of drying time, the PLC control system will activate the motor and gearbox to remove the rubber from the drying chamber.

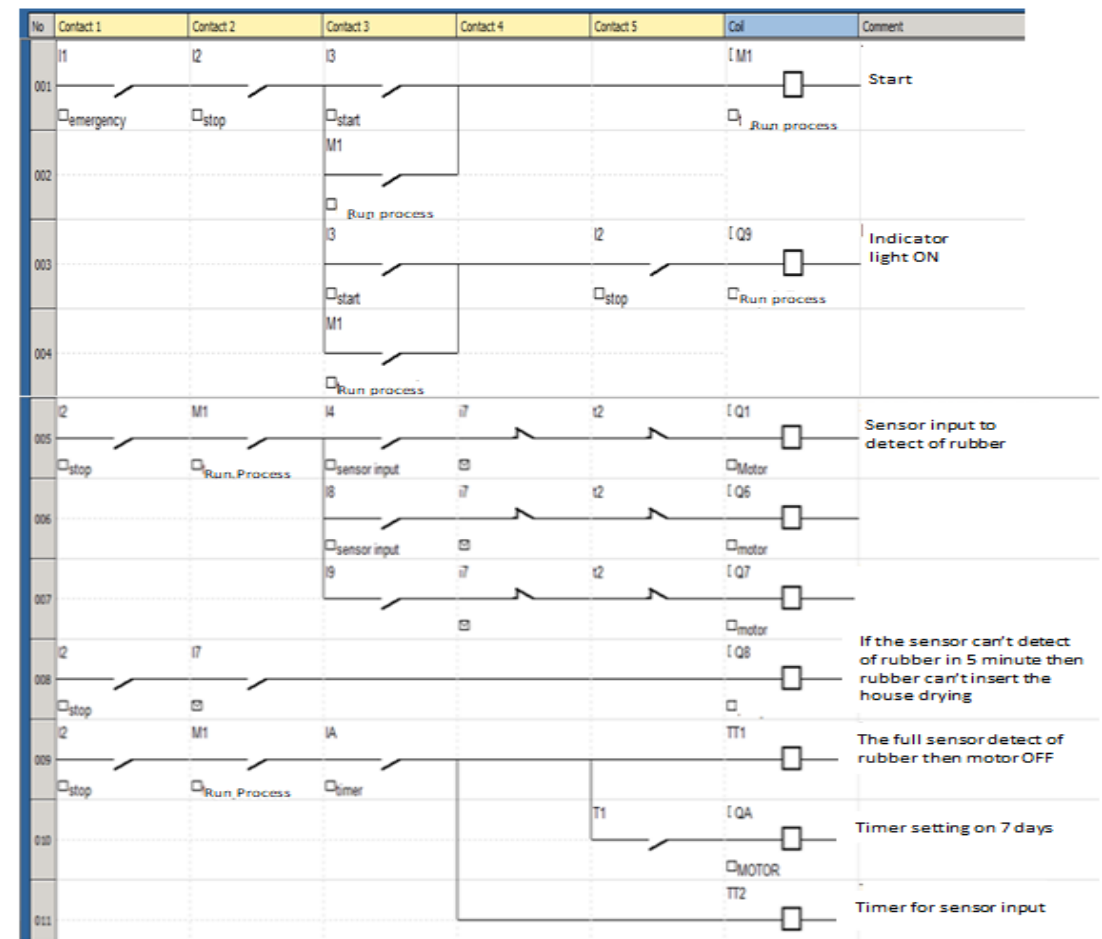

Fig. 8 Ladder program PLC for the control system of rubber dryer machine

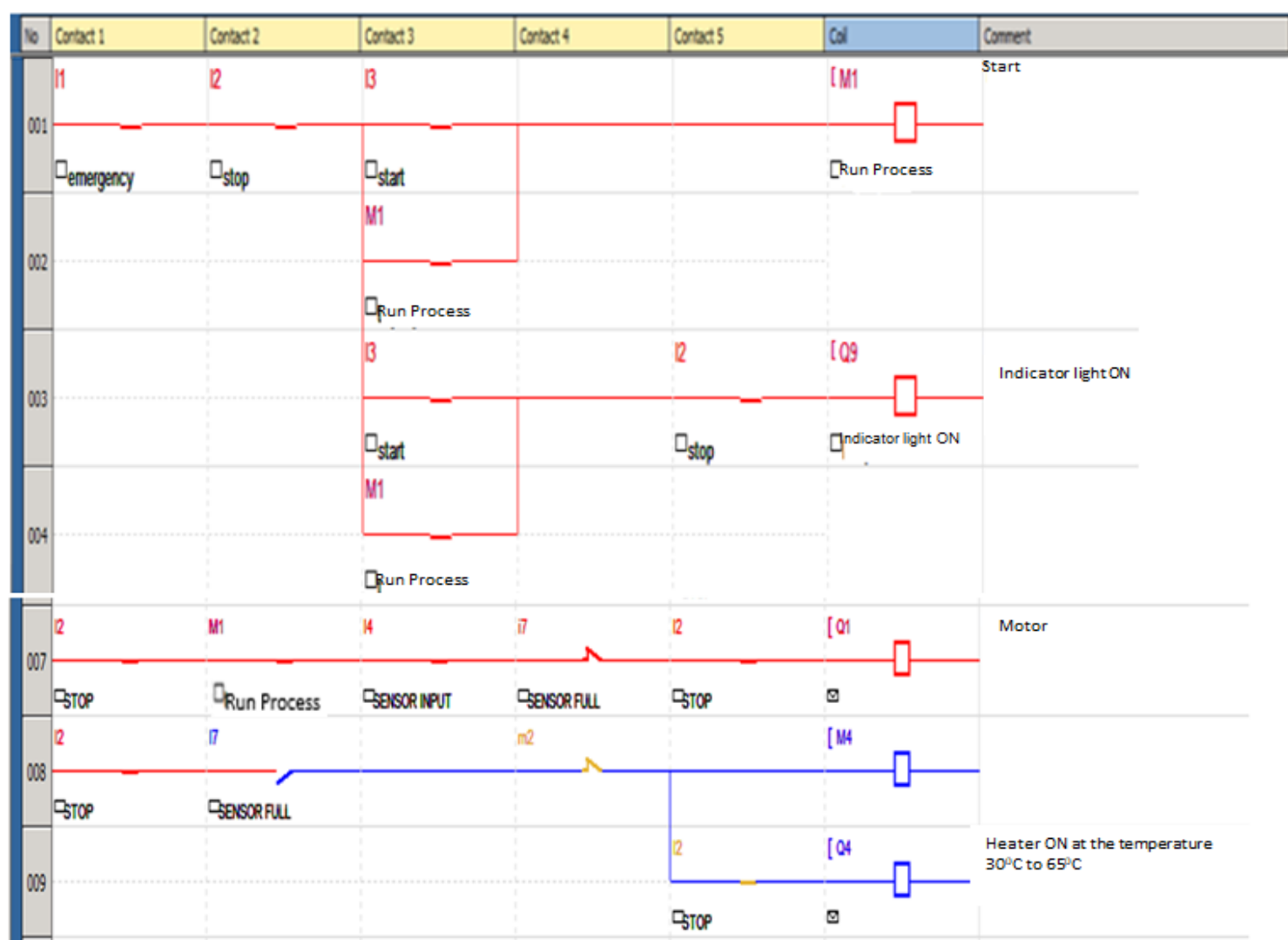

Fig. 9 Testing of ladder program PLC for function component control system of rubber dryer machine

Applying Programmable Logic Control (PLC) for Control Motors, Blower and Heater in the Rubber Drying Processing (Hendra) 
Table 3 shows the arrangement of rubber inlet and test results of distance sensor with rubber dimension $500 \times 400 \times 5(\mathrm{~mm})$, which can be seen that rubber- 1 movement requires voltage $220 \mathrm{~V}$ and current $0.21 \mathrm{~A}$. The working time of sensor 1 to detect rubber entering the drying chamber door is 3.38s, waiting time 0.1s. Sensor 1 will provide information to the PLC to activate the motor to pull the rubber towards the entrance to the drying chamber. Sensor 2 detects the movement of rubber- 1 towards the entrance of the rubber drying chamber to the dryer chamber with a working time of $3.38 \mathrm{~s}$ and a waiting time of $0.14 \mathrm{~s}$. Sensor 3 showed rubber movement to the drying chamber for $3.36 \mathrm{~s}$ and a waiting time of $0.1 \mathrm{~s}$. On the rubber- 2 line, it can be seen that sensor 1 uses a working time of $3.35 \mathrm{~s}$ and a waiting time of $0.2 \mathrm{~s}$ to detect the arrival of rubber and provide information to the PLC to activate the drive motor until the rubber-2 moves towards the entrance to the drying room, the second sensor requires the same time as sensor one and sensor 2 require a companion time of $3.38 \mathrm{~s}$ and $0.1 \mathrm{~s}$ waiting time for the rubber to enter the drying chamber.

The 3rd rubber required a time for sensor 1 to detect the arrival of the rubber at $3.38 \mathrm{~s}$ and a waiting time at $0.11 \mathrm{~s}$. For sensor 2, the working time of transferring the rubber to the drying chamber is shorter, i.e., $3.35 \mathrm{~s}$ and $0.11 \mathrm{~s}$, and sensor 3 requires $3.37 \mathrm{~s}$ and $0.12 \mathrm{~s}$ to detect the 3 rd rubber already present in the drying chamber. The entry of the 4 th rubber into the drying chamber is detected by sensor 1 with a working time of $3.38 \mathrm{~s}$ and $0.15 \mathrm{~s}$ of waiting time. As sensor 2 moves the $3 \mathrm{rd}$ rubber into the inlet chamber for $3.37 \mathrm{~s}$ and $0.2 \mathrm{~s}$ of waiting time of sensor three stacks the rubber in the drying chamber with working times of $3.37 \mathrm{~s}$ and $0.12 \mathrm{~s}$. For the fourth to ninth rubber movements, it can be seen that the working time ranges from $3.35 \mathrm{~s}$ to $3.39 \mathrm{~s}$, and the waiting time is $0.1 \mathrm{~s}$ to $0.4 \mathrm{~s}$ for sensor 1 . On sensor 2 , it is $3.34 \mathrm{~s}-3.39 \mathrm{~s}$ and $0.1 \mathrm{~s}-0.2 \mathrm{~s}$ for waiting for time, and sensor 3 takes $3.35 \mathrm{~s}-3.38 \mathrm{~s}$ and a waiting time of $0.1 \mathrm{~s}$.

On the 9th rubber, the 1-time sensor to detect and provide information for the rubber entering the PLC to activate the motor is $3.35 \mathrm{~s}$ and $0.4 \mathrm{~s}$ for the waiting time. Meanwhile, sensor one and sensor 3 have working times of $3.38 \mathrm{~s}$ and $3.37 \mathrm{~s}$ with waiting times of $0.1 \mathrm{~s}$.

Table 3 Testing data of sensor proximity with dimension rubber 500 x 400 x $5(\mathrm{~mm})$

\begin{tabular}{|c|c|c|c|c|c|c|c|c|c|}
\hline \multirow{3}{*}{$\begin{array}{c}\text { Number } \\
\text { of } \\
\text { rubber }\end{array}$} & \multirow{3}{*}{$\begin{array}{c}\text { Length } \\
(\mathrm{mm})\end{array}$} & \multirow{3}{*}{$\begin{array}{c}\text { Voltage } \\
\text { (V) }\end{array}$} & \multirow{3}{*}{$\begin{array}{c}\text { Current } \\
\text { (A) }\end{array}$} & \multicolumn{6}{|c|}{ Time of rubber insert on the drying house (s) } \\
\hline & & & & \multicolumn{2}{|c|}{ Sensor 1} & \multicolumn{2}{|c|}{ Sensor 2} & \multicolumn{2}{|c|}{ Sensor 3} \\
\hline & & & & ON & OFF & $\mathbf{O N}$ & OFF & ON & OFF \\
\hline 1 & & & & 3.38 & 0.10 & 3.38 & 0.14 & 3.36 & 0.10 \\
\hline 2 & & & & 3.35 & 0.20 & 3.35 & 0.20 & 3.38 & 0.10 \\
\hline 3 & & & & 3.38 & 0.11 & 3.35 & 0.11 & 3.37 & 0.12 \\
\hline 4 & 500 & 220 & 0.21 & 3.38 & 0.15 & 3.37 & 0.20 & 3.35 & 0.10 \\
\hline 5 & & & & 3.39 & 0.10 & 3.36 & 0.11 & 3.35 & 0.10 \\
\hline 6 & & & & 3.37 & 0.20 & 3.34 & 0.10 & 3.37 & 0.10 \\
\hline 7 & & & & 3.38 & 0.21 & 3.39 & 0.17 & 3.38 & 0.10 \\
\hline 8 & & & & 3.39 & 0.13 & 3.38 & 0.10 & 3.36 & 0.10 \\
\hline 9 & & & & 3.35 & 0.40 & 3.38 & 0.10 & 3.37 & 0.10 \\
\hline
\end{tabular}

The results of performance test each component of the automatic rubber dryer machine with PLC control system obtained:

1. Performance test data of proximity sensor 1 , sensor 2 , and sensor 3 using wet rubber with dimension $500 \times 400 \times 5(\mathrm{~mm})$ show that the function of the proximity sensor works at a voltage of $220 \mathrm{~V}$ with a current of $0.21 \mathrm{~A}$. The time required to detect rubber and move in the drying chamber is $3.35 \mathrm{~s}-3.39 \mathrm{~s}$ with a stop time interval of $0.1 \mathrm{~s}-0.3 \mathrm{~s}$. This indicates the sensor is able to function to detect and provide information to the PLC to activate the motor, and the gearbox moves the rubber hanger hook chain to the dryer chamber.

2. The $A C$ motor test data show that the motor is active $(\mathrm{ON})$ at a voltage of $220 \mathrm{~V}$ with a current of $8.27 \mathrm{~A}$ and stop (OFF) at a current of 0A, as shown in Table 4.

3. The heater test data show that the heater requires a current of $1.99 \mathrm{~A}$ at a voltage of $220 \mathrm{VAC}$ for active $(\mathrm{ON})$ and stop $(\mathrm{OFF})$ at a current of $0 \mathrm{~A}$, as shown in Table 5. The heater is arranged to work on a rubber dryer with a working temperature of $30^{\circ} \mathrm{C}$ into $60^{\circ} \mathrm{C}$. If the temperature in the drying chamber is less than $30^{\circ} \mathrm{C}$ then the heater will be active $(\mathrm{ON})$ using a current of $8.27 \mathrm{~A}$ and other hands if the drying room temperature is more than $60^{\circ} \mathrm{C}$, then the heater stops (OFF), and the evacuation blower will actively remove air from the drying chamber rubber.

4. Blower test data show that the motor will be active $(\mathrm{ON})$ at a voltage of $220 \mathrm{~V}$ with a current of $0.75 \mathrm{~A}$ and stop (OFF) at a current $0 \mathrm{~A}$, as shown in Table 6. The blower used serves as a conduit of hot air in the 
drying chamber until dissipated evenly (the constant temperature at $40^{\circ} \mathrm{C}-50^{\circ} \mathrm{C}$ ) and distribute hot air out of the drying chamber if the drying room temperature exceeds $60^{\circ} \mathrm{C}$.

Table 4 Testing data performance of motor AC

\begin{tabular}{ccc}
\hline Function & Voltage $\left(\mathrm{V}_{\mathrm{AC}}\right)$ & Current $(\mathrm{A})$ \\
\hline ON & 220 & 8.27 \\
OFF & 220 & 0 \\
\hline & Table 5 Testing data performance of heater \\
\hline Function & Voltage $\left(\mathrm{V}_{\mathrm{AC}}\right)$ & Current $(\mathrm{A})$ \\
\hline ON & 220 & 1.99 \\
OFF & 220 & 0 \\
\hline
\end{tabular}

Table 6 Testing data performance of blower evacuation

\begin{tabular}{ccccc}
\hline Output & Function & $\begin{array}{c}\text { Temp } \\
\left({ }^{\circ} \mathrm{C}\right)\end{array}$ & $\begin{array}{c}\text { Output } \\
\left(\mathrm{V}_{\mathrm{AC}}\right)\end{array}$ & $\begin{array}{c}\text { Current } \\
(\mathrm{A})\end{array}$ \\
\hline \multirow{2}{*}{ Blower 1} & ON & $45-100$ & 220 & 0.75 \\
& OFF & $<43$ & 220 & 0 \\
Blower 2 & ON & $45-100$ & 220 & 0.74 \\
& OFF & $<43$ & 220 & 0 \\
Blower 3 & ON & $45-100$ & 220 & 0.75 \\
& OFF & $<43$ & 220 & 0 \\
Blower 4 & ON & $45-100$ & 220 & 0.75 \\
& OFF & $<43$ & 220 & 0 \\
\hline
\end{tabular}

As shown in the testing results of proximity sensors 1,2 , and 3 , there is a difference in the stop time value of the input sensor and the rubber displacement from $0.01 \mathrm{~s}$ to $0.3 \mathrm{~s}$, especially on sensor 1 . In sensor 2 , it has similarities value with sensor one but different for sensor 3 , where on sensor 3 , the stop time values of the input sensor and the rubber number displacement 1 to 8 are almost the same. This is due to several conditions, namely: the sensor is affected by external light so that the sensor cannot detect the incoming rubber. In addition, this is also due to the nature of the sensor having a delay in reading the detected object.

The testing results of the wet rubber drying process using solar energy showed a temperature distribution from 06:00 to $22: 00$ between $27^{\circ} \mathrm{C}$ to $46^{\circ} \mathrm{C}$ with 53-224 lux sunlight, as shown in Fig. 10. This indicates that with the use of the control system on the rubber dryer machine, the same working temperature will be obtained $\left(40^{\circ} \mathrm{C}-50^{\circ} \mathrm{C}\right)$ with the temperature setting range using PLC $30^{\circ} \mathrm{C}-60^{\circ} \mathrm{C}$.

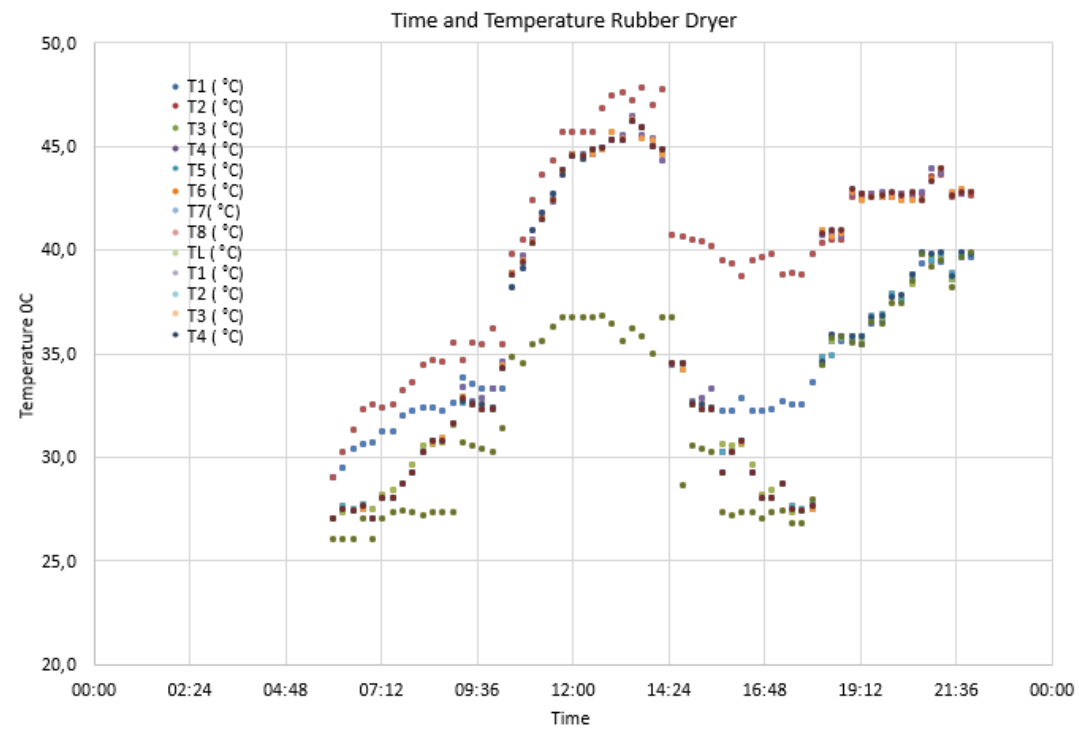

Fig. 10 Result testing of time and temperature distribution in the drying chamber

The process of drying the rubber and the resulting product can be seen in Fig. 11. The result of the rubber using this automatic rubber dryer machine shows good quality where there are no air bubbles in the dried

Applying Programmable Logic Control (PLC) for Control Motors, Blower and Heater in the Rubber Drying Processing (Hendra) 
rubber. Compared with the results of rubber drying based on standards from Company X (see Fig. 6), the drying result with this rubber dryer has met the standard requirements.

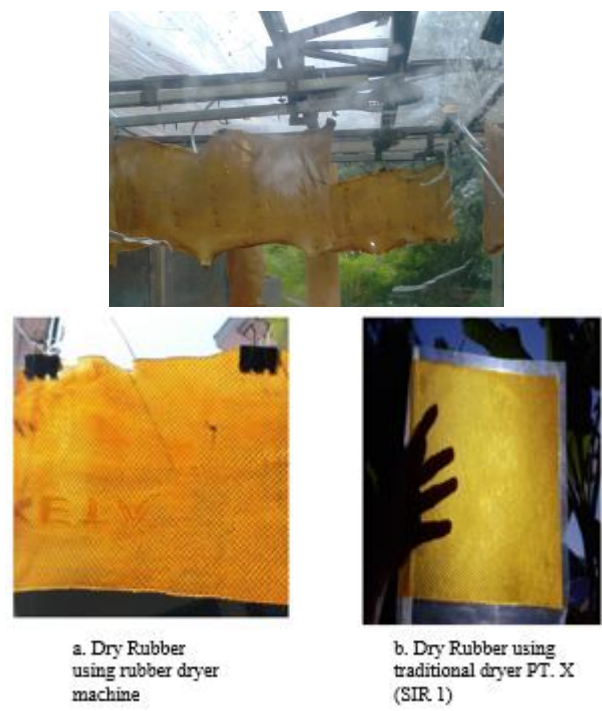

Fig. 11 Quality result testing of dry rubber

\section{CONCLUSION}

From the data experimental testing of automatic rubber dryer control system using PLC it can be concluded that the control system can be working fairly with a voltage of each component 220V such as Motor, heater, the blower is active $(\mathrm{ON})$ with the current of 8.27A and stop (OFF) at a current of 0A. The heater requires a current of $1.99 \mathrm{~A}$ for active $(\mathrm{ON})$ and stop $(\mathrm{OFF})$ at a current of $0 \mathrm{~A}$, and lower will be active $(\mathrm{ON})$ with a current of $0.75 \mathrm{~A}$ and stop $(\mathrm{OFF})$ at a current $0 \mathrm{~A}$. The performance sensor on the components of the automatic rubber dryer machine using PLC works at a voltage of $220 \mathrm{~V}$ and current of $0.21 \mathrm{~A}$. The time required to detect rubber and move in the drying chamber is $3.35 \mathrm{~s}-3.39 \mathrm{~s}$ with a stop time interval of $0.1 \mathrm{~s}-0.3 \mathrm{~s}$. The automatic rubber drying machine control system using PLC can work well and produce quality rubber according to the quality standard for SIR1.

\section{Acknowledgments}

Thank you to the Government of the Republic of Indonesia through the Ministry of Research, Technology and Higher Education of the Republic of Indonesia, who has funded this research at MP3EI/PSN-I Research Grants in 2019 and LPPM University of Bengkulu.

\section{REFERENCES}

[1] A. Vachlepi, "Peningkatan Mutu Blanket Karet Alam Melalui Proses Predrying Dan Penyemprotan Asap Cair," Majalah Kulit, Karet, dan Plastik, vol. 33, no. 1, pp. 1-20, 2017. https://doi.org/10.20543/mkkp.v33i1.1702

[2] Hendra, A. S. Yulianto, A. Indriani, Hernadewita, and Hermiyetti, "Control Systems of Rubber Dryer Machinery Components using Programmable Logic Control (PLC)," IOP Conference Series: Materials Science and Engineering, 307, p. 012021, 2018. https://doi.org/10.1088/1757-899X/307/1/012021

[3] Hendra, A. Indriani, Hernadewita, Y. Rizal, "Assembly Programmable Logic Control (PLC) in the Rotary Dryer Machine for Processing Waste Liquid System,” Applied Mechanics and Materials, Vol. 842, pp. 319-323, 2016. https://doi.org/10.4028/www.scientific.net/AMM.842.319

[4] E. R. Alphonsus, M. O. Abdullah, "A Review on The Applications of Programmable Logic Controllers (PLCs)," Renewable and Sustainable Energy Reviews, vol. 60, pp. 1186-1204, July 2016. https://doi.org/10.1016/j.rser.2016.01.025

[5] R. Langmann, and M. Stiller, "The PLC as a Smart Service in Industry 4.0 Production Systems," Appl. Sci., vol. 9, no. 18,3815 , pp. $1-20,2019$. https://doi.org/10.3390/app9183815

[6] F. Fathahillah, M. Siswanto, M. Fauziyah, R. Parlindungan, R.I. Putri, and Y.G. Roh, "Implementation of Programmable Logic Controller in Multi Machine Operations with Product Sorting and Packaging Based on Colour Detection," IOP Conf. Series: Materials Science and Engineering, vol. 732, p. 012069, 2020. https://doi.org/10.1088/1757-899X/732/1/012069 
[7] Fahmizal, D. B. Pratama, A. Priyatmoko, M. R. F. Rahman, "Otomatisasi Proses Produksi Cat Berbasis Simulator PLC TWIDO TWDLMDA20DTK," Jurnal Sains dan Teknologi, Vol. 7, no. 1, pp. 49-58, 2018. https://doi.org/10.23887/jst-undiksha.v7i1.12900

[8] R. Afrino, A. Triwiyatno, Sumardi, "Perancangan Sistem Otomatisasi Berbasis Programmable Logic Controller (PLC) OMRON CPM1A pada Prototype Alat Pengolah Susu Murni Menjadi Susu Pasteurisasi Aneka Rasa," Jurnal Transient, vol.6, no. 1, pp. 37-44, 2017. https://doi.org/10.14710/transient.6.1.37-44

[9] L. A. Hakim, R. A. Anugrah, "Perancangan Sistem Otomasi Proses Pelubangan Kartu Tekstil Jacquard Pada Mesin Punching di PT. Buana Intan Gemilang," Jurnal Rekayasa Sistem \& Industri, vol 4, no. 1, pp. 68-75, 2017. https://doi.org/10.25124/jrsi.v4i01.249

[10] G. A. Laksmana, P. Santoso, F. Pasila, “Aplikasi Untuk Memonitor PLC pada Mesin Filling Dan Capping,” Jurnal Teknik Elektro, vol. 10, no. 2, pp. 48-53, 2017.

[11] T. B. Dwinugroho, "Implementasi Programmable Logic Control (PLC) Pada Gripper Mesin Batik Cap Otomatis Berbasis CNC", Industrial Engineering Journal of the University of Sarjanawiyata Tamansiswa, Vol. 1, no. 1, pp. 40-50, 2017.

[12] Y. Birbir, H. S. Nogay, "Design and Implementation of PLC-Based Monitoring Control System for Three-Phase Induction Motors Fed by PWM Inverter," International Journal of Systems Applications, Engineering \& Development, vol. 2, no. 3, 2008.

[13] I. Setiawan, Programmable Logic Controller dan Teknik Perancangan Sistem Kontrol, Penerbit Andi Yogyakarta, 2006.

[14] M. S. Saleh, K. G. Mohammed, A. Z. Sameen, "Design And Implementation Of PLC-Based Monitoring and Sequence Controller System," Journal of Advanced Research in Dynamical and Control Systems, vol. 10, no. 02, pp. 2281-2289, 2018.

[15] J. R. Hackworth, and F. D. Hackworth, Jr., Programmable Logic Controllers: Programming Methods and Applications, New Jersey: Pearson, 2004.

[16] G. P. Zimmerman, Programmable Logic Controllers, and Ladder Logic, Department of Humanities South Dakota School of Mines and Technology, 2008.

[17] K. Collins, PLC Programming for Industrial Automation, Kindle Edition, 2016

[18] A. Indriani, Hendra, and Y. Witanto, "Error of Assembly Microcontroller Arduino Mega and ATmega in the Control of Temperature for Heating and Cooling System,” Applied Mechanics and Materials, vol. 842, pp. 319-323, 2016. https://doi.org/10.4028/www.scientific.net/AMM.842.324

[19] P. Naphona, S. Wiriyasarta, N. Naphon," Thin Rubber Sheet Drying Curve Characteristics of Fresh Natural Rubber Latex," International Journal of Applied Engineering Research, vol. 13, no. 10, pp. 8447-8454, 2018.

\section{BIOGRAPHY OF AUTHORS}

Hendra is Associate Professor in Mechanical Engineering Dept. Faculty of Engineering University of Sultan Ageng Tirtayasa, Banten, Indonesia. Email: hendra@untirta.ac.id

Pebriyanto S. finished his Bachelor in Mechanical Engineering University of Bengkulu, Bengkulu, Indonesia. Email: h7f1973@yahoo.com

Hernadewita is an Associate Professor at Magister Industrial Engineering University of Mercubuana Jakarta, Indonesia. Email: hernadewita@mercubuana.ac.id

Hermiyetti is an Associate Professor in the Faculty of Economics University of Bakrie Jakarta, Indonesia. Email: hermiyetti@bakrie.ac.id

Yoserizal was finished his Bachelor in Mechanical Engineering at Andalas University, Indonesia. Email: rizal_yose@yahoo.co.id 